\title{
Nilai pendidikan profetik dalam filantropi masyarakat Grenden, Jember
}

\author{
Miftakhuddina,1,* \\ a Pendidikan Dasar (S2) Universitas Negeri Yogyakarta, Jl. Colombo, No. 1, 55281, Indonesia \\ 1 tuplick110@gmail.com
}

Received Aug, 122021

Revised Aug, 232021

Accepted Aug, 242021

\begin{abstract}
ABSTRAK
Selama ini, filantropi tradisional kurang banyak dikaji dalam perspektif ilmu pendidikan, padahal ia berpotensi menjadi rujukan pendidikan karakter berbasis kearifan lokal. Penelitian ini bertujuan menginterpretasi nilai-nilai pendidikan dalam filantropi tradisional masyarakat Grenden. Menggunakan desain etnografi yang dilakukan sepanjang 2018-2020, penelitian ini berhasil mengungkap sejumlah nilai pendidikan dari aktivitas filantropis masyarakat golongan petani, penambang gamping, dan nelayan. Analisis lebih lanjut mengungkapkan bahwa landasan filosofis dan pedoman praktis dari filantropi itu didasarkan atas pemahaman religi islam khas kejawen. Temuan penelitian ini berkontribusi kepada pengembangan ilmu pendidikan, terutama pendidikan karakter. Penelitian ini menawarkan solusi atas masalah pendidikan karakter yang selama ini harus diselenggarakan dengan menunjukkan role model terlebih dahulu. Oleh sebab itu, implikasi penelitian ini adalah berupa kritik dan koreksi atas penyelenggaraan pendidikan karakter di sekolah menenah dan pendidikan tinggi yang tidak berdasarkan nilai-nilai kearifan masyarakat. Termasuk dalam objek kritik penelitian ini adalah dasar-dasar pendidikan karakter yang ditawarkan Thomas Lickona, dan sebagai gantinya penelitian ini mempromosikan nilai pendidikan karakter berbasis kearifan masyarakat Indonesia sebagaimana digaungkan oleh Ki Hadjar Dewantara.

\section{The value of prophetic education in community philanthropy Grenden, Jember}

ABSTRACT

To date, traditional philanthropy has not been widely studied in the perspective of educational sciences. In fact, traditional philanthropy has the potential to be a reference for character education based on local wisdom. This study aims to interpret educational values in the traditional philanthropy of the Grenden society. Using an ethnographic design conducted throughout 2018-2020, this study succeeded in revealing a number of educational values from the philanthropic activities of the class of farmers, limestone miners, and fishermen. Further analysis reveals that the philosophical foundation and practical guidelines of philanthropy are based on the understanding of the Javanese Islam. The findings of this study contribute to the development of educational science, especially character education. This research offers a solution to the problem of character education that has been carried out by showing a role model first. Therefore, the implications of this research are in the form of criticism and correction of the implementation of character education in secondary school and higher education institutions that is not based on the values of local wisdom. Included in the object of this research criticism are the basics of character education offered by Thomas Lickona, and instead this research promotes the value of character education based on the wisdom of the Indonesian people as echoed by Ki Hadjar Dewantara.
\end{abstract}

This is an open-access article under the CC-BY-SA license

\section{Pendahuluan}

Sejak diundangkannya UU No. 20 Tahun 2003 tentang Sistem Pendidikan Nasional, pendidikan karakter menjadi suatu isu yang banyak dikaji dalam berbagai diskursus akademik. Sebab, dalam pasal 3 UU itu tersirat bahwa tujuan pendidikan nasional bukan hanya membentuk manusia yang cakap secara intelektual, melainkan juga beriman dan 
berkarakter. Paradigma pendidikan kemudian dikembangkan dengan menegaskan tugas guru bukan lagi transfer of knowledge semata, tetapi juga transfer of values dan transfer of skills. Beberapa bidang studi yang dianggap sangat kontributif terhadap pembentukan karakter turut mendapat perhatian serius, seperti Ilmu Sosial, Agama, dan Pendidikan Kewarganegaraan (Miftakhuddin et al., 2019). Pemilihan bidang studi ini didasarkan pada lima jenis karakter utama yang diusulkan Kemendiknas (2011), yaitu melingkupi karakter dalam hubungannya dengan: tuhan, sesama manusia, lingkungan, bangsa-negara (nasionalisme), dan diri sendiri.

Praktis, apa yang dimaksud karakter adalah kepribadian yang mencerminkan nilai dan norma sosial di masyarakat. Individu yang karakternya terdidik, idealnya selalu berperilaku baik sebagaimana nilai yang dianut oleh masyarakat tempat tinggalnya. Bahkan dalam tingkatan yang lebih tinggi, individu yang karakternya terdidik bisa berperilaku mencerminkan nilai di luar nilai yang dipromosikan oleh masyarakatnya. Ini terjadi karena di atas nilai dan norma lainnya, terdapat norma kesusilaan yang bersumber dari hati nurani dan sifatnya universal. Norma itulah yang pasti berhasil diinternalisasi oleh individu dengan karakter terdidik.

Sampai hari ini, isu pendidikan karakter masih menjadi suatu hal yang mendesak untuk dikaji, karena menurut temuan Salirawati (2021), pencanangan pendidikan karakter yang sudah berlangsung sejak 2010 rupanya belum memberikan hasil yang baik. Beberapa buktinya ialah kenakalan pelajar pada usia anak dan remaja yang banyak dipublikasikan oleh media masa, seperti: perilaku tidak hormat kepada guru (Detik.com, 2018), pelanggaran terhadap norma hukum dan norma agama (Jawapos.com, 2021), dan kekerasan verbal melalui platform digital (Kompas.com, 2021).

Tanpa mengesampingkan salah satu faktor kependidikan, perkembangan pendidikan karakter di Indonesia bisa dikaji dari segi kelembagaan (institusional), sosial, dan kultural. Dari segi kelembagaan, menurut Noormawanti (2017), pendidikan karakter kurang berkembang karena masih adanya sekolah Indonesia yang terlalu memprioritaskan pencapaian akademis. Sementara visi dan komitmen sekolah terhadap suksesi pendidikan karakter justru kurang diperhatikan. Adapun dari segi sosial dan kultural, pendidikan karakter sulit berkembang karena ketidaksamaan visi dalam tri pusat pendidikan (sekolah, keluarga, dan masyarakat).

Menurut Lubis (2019), proses dan output pendidikan karakter bisa dicapai dengan baik jika terjadi keselarasan antar tri pusat pendidikan. Ketidakselarasan itu sulit dicapai karena keluarga dan masyarakat kerap kali punya perspektif berbeda dengan sekolah tentang pendidikan karakter. Oleh karenanya, selain perbedaan standar moral masingmasing kelompok masyarakat, penyebab rendahnya ketercapaian pendidikan karakter ditinjau dari perspektif ilmu pendidikan ialah tidak didapatkannya role model yang layak oleh siswa. Sebagaimana teori belajar sosial yang diperkenalkan Bandura (1977), segala sesuatu yang dipelajari anak adalah segala sesuatu yang mereka lihat dan mampu mereka tiru. Ini berimplikasi kepada besarnya risiko manakala guru mencontohkan perilaku yang mencerminkan buruknya karakter personal (teladan buruk).

Sebagai konsekuensi lebih lanjut, role model yang tidak layak mengakibatkan gagalnya pendidikan karakter pada khususnya, dan gagalnya pembentukan output pendidikan yang berkualitas pada umumnya. Sebab menurut menurut temuan riset Dyer et al. (2011), sekitar 80\% keberhasilan seseorang dalam berkarir, bersosialisasi, dan berkreasi menciptakan pemecahan masalah cenderung banyak ditentukan oleh karakter atau kepribadian. Sedangkan 20\% sisanya ditentukan oleh kecakapan akademis atau keterampilan intelektual. Sehubungan dengan hal itu, temuan Salirawati (2021) di atas turut menegaskan bahwa urgensi pelaksanaan pendidikan karakter yang berkualitas seperti dikemukakan Dyer et al. (2011) belum terfasilitasi dengan baik.

Sejauh penelusuran penulis belum ada penelitian yang secara fundamental bisa mengatasi research gap tersebut. Salah satu sebabnya ialah pendidikan karakter tidak diselenggarakan dalam satu bidang studi yang berdiri sendiri, melainkan terintegrasi ke 
dalam bidang studi lain atau bentuk pengembangan diri (Judiani, 2010). Sebagai alternatif penyelesaiannya, maka perlu dilakukan kajian untuk menemukan pendekatan baru untuk menyelenggarakan pendidikan karakter. Terlebih lagi seringkali nilai-nilai budaya dan karakter perlu diajarkan dengan modifikasi dan adaptasi terhadap metode-metode dan sumber-sumber pembelajaran yang baru (Gufron et al., 2017).

Sehubungan dengan kebutuhan itu, hasil studi pendahuluan (preliminary studies) di Desa Grenden mengungkapkan adanya potensi tradisi masyarakat yang bisa berkontribusi terhadap penyelesaian masalah pendidikan karakter yang ada. Potensi tersebut ialah tradisi filantropis yang dilakukan masyarakat golongan petani.

Di Grenden, masyarakat golongan petani punya tradisi untuk menyumbangkan sebagian kecil hasil panennya kepada tetangga yang dianggap sebagai keluarga prasejahtera. Terlepas dari berapapun dan apapun hasil panen yang diberikan (gabah, jagung, kedelai, dan lainnya), mereka tetap memberikan hasil panen sebagai bentuk kepedulian dan ekspresi kemanusiaan yang jarang dijumpai di kelompok masyarakat lain. Apabila ditelaah lebih lanjut, usaha ini tidak lain merupakan representasi satu dari dua puluh karakter pokok yang dikemukakan Kemendiknas (2011), yaitu peduli sosial dan lingkungan. Bahkan jika ditinjau dari perspektif lain, filantropi ini juga merupakan representasi dari karakater religius. Sebab sebagai pemeluk islam, masyarakat Grenden meyakini bahwa memberikan sedekah atau membantu tetangga dan/atau saudara merupakan kewajiban bagi setiap muslim. Artinya, mereka menyumbang untuk menjalankan kewajibannya.

Demikianlah kearifan lokal yang khas di masyarakat Grenden mengandung unsur pendidikan karakter. Perlu ditegaskan bahwa temuan di atas merupakan contoh unsur pendidikan karakter pada masyarakat golongan petani. Penelitian ini secara lebih lengkap dan cermat mengkaji unsur pendidikan karakter lainnya yang berasal dari komposisi masyarakat lain, seperti ulama, penambang, pengusaha, dan lain-lain. Kajian lanjutan ini diperlukan karena diasumsikan setiap profesi di pedesaan mempunyai motivasi khas yang melatarbelakangi tindakan dan moralitas mereka (Rahardjo, 2017).

Berdasarkan latar belakang di atas, penelitian ini dilaksanakan dengan merujuk kepada masalah pokok: bagaimana nilai pendidikan karakter dalam filantropi masyarakat Grenden?. Rumusan masalah tersebut kemudian dirinci menjadi dua pertanyaan penelitian khusus berikut: (1) mengapa masyarakat Grenden melakukan aktivitas filantropis?, dan (2) apa saja dasar filosofis maupun praktis yang melandasi filantropis tersebut?. Terjawabnya dua pertanyaan penelitian tersebut berkontribusi dalam mengatasi masalah-masalah pendidikan karakter yang selama ini sulit diselesaikan.

\section{Metode}

Penelitian kualitatif ini dilaksanakan menggunakan desain etnografi sejak 2018-2020 di Desa Grenden, Kec. Puger, Jember. Secara khusus, desain etnografi di penelitian ini adalah microethnography, karena fokus kajiannya merujuk kepada satu entitas spesifik (Berg, 2004), yaitu nilai-nilai pendidikan dalam filantropi masyarakat Grenden. Desain penelitian ini dipilih karena paling sesuai dengan tujuan dilakukannya penelitian, yaitu memahami budaya masyarakat dari perspektif subjek (insiders). Proses memahami ini dilakukan dengan berpartisipasi dalam kehidupan sehari-hari subjek sehingga diperoleh gambaran nilai dan kepercayaan yang melatarbelakangi perilaku dan kehidupan sosial subjek (Schreiber \& Asner-Self, 2011). Oleh sebab itu, pengambilan data dalam riset etnografi ini dilakukan menggunakan metode-metode kualitatif, yaitu observasi partisipatif, wawancara tidak terstruktur, dan catatan anekdot (Spradley \& McCurdy, 2012).

Data emic yang diperoleh kemudian dianalisis secara kualitatif mengikuti langkahlangkah yang diusulkan Miles et al. (2014), meliputi data condensation, data display, dan conclusion drawing/verification. Pada fase data condensation, reduksi data ditempuh 
menggunakan teknik triangulasi sumber sehingga diperoleh data valid. Data valid inilah yang kemudian diinterpretasi sehingga menjadi data etic. Deskripsi hasil interpretasi ini dikategorisasikan secara tematik ke dalam pembahasan-pembahasan di bawah ini (data display) sehingga diperoleh simpulan yang representatif.

\section{Hasil dan pembahasan}

Bagi masayarakat Jember, aktivitas filantropi bukan merupakan "barang baru". Beberapa contoh filantropi (amal) pernah diungkap dalam penelitian Tamin (2011) yang menjelaskan bagaimana masyarakat petani jeruk di Kec. Umbulsari melakukan kegiatan filantropi dalam bentuk karitas dan pemberdayaan sekaligus. Demikian juga dengan pengabdian Unej Mengajar di daerah tertinggal dalam penelitian Miftakhuddin (2019), yang melakukan kegiatan filantropi dalam bidang pendidikan, literasi, dan ekonomi sekaligus melalui skema pemberdayaan. Selain itu, banyak juga gerakan-gerakan filantropi lain yang didasari oleh tingginya kepedulian sosial dan rasa kemanusiaan. Hanya saja dalam filantropi yang selama ini dibahas dalam sejumlah literatur dan hasil riset, merupakan filantropi modern, yaitu kedermawanan yang diwujudkan dalam rangka melakukan perubahan dan keadilan sosial secara terstruktur untuk mengatasi berbagai masalah kemiskinan, kemanusiaan, pendidikan, gender, dan lingkungan (Jusuf, 2007). Karenanya, filantropi modern biasanya dilakukan oleh suatu organisasi atau lembaga untuk membantu mengatasi masalah sosial yang kompleks.

Namun berbeda dengan filantropi di atas, aktivitas filantropis yang berhasil dikaji dalam penelitian ini tergolong dalam filantropi tradisional, sebab bentuk kedermawanan karitas diwujudkan secara tidak terstruktur dan ditujukan untuk mengatasi satu masalah khusus, yaitu masalah ekonomi/kemiskinan. Lebih uniknya, filantropi dilakukan dalam lingkup internal kemasyarakatan dari satu individu kepada individu lainnya. Berdasarkan analisis terhadap hasil observasi partisipatif dan catatan anekdot, umumnya filantropi di Grenden dilakukan oleh tiga golongan masyarakat paling dominan, yaitu petani, penambang gamping, dan nelayan. Meski begitu, bukan berarti masyarakat di luar golongan itu tidak melaksanakan aktivitas amal. Golongan minoritas yang terdiri dari pegawai negeri, pengusaha toko, dan ulama lokal juga menyumbangkan amal dalam berbagai bentuk, baik amal yang sifatnya pemberian maupun pemberdayaan.

\subsection{Filantropi petani}

Berdasarkan analisis data kualitatif, diperoleh gambaran bahwa keluarga prasejahtera bukanlah satu-satunya target pemberian. Beberapa petani memberikan sebagian kecil hasil panen juga kepada orang yang lebih tua (sepuh) dan keluarga baru. Mengenai alasan mengapa mereka memberikan sumbangan kepada individu-individu tersebut, subjek petani berinisial MW melalui wawancara mengatakan dalam bahasa Jawa yang sangat kental: "Ya kan orang tua yang sepuh sudah gak bisa kerja. Anaknya memang masih ada, ya paduli juga, tapi kan ya namanya tetangga gak ada salahnya baik sama orang. Selama ini kan beliau juga baik". Sedangkan alasan petani memberi sumbangan hasil panen kepada keluarga baru ialah karena mereka diasumsikan sebagai rumah tangga baru yang masih membutuhkan banyak dukungan dari orang yang lebih tua. Oleh sebab itu, salah satu dukungan yang bisa diberikan adalah bahan makanan pokok (hasil panen).

Selain pemberian hasil yang diserahkan dari rumah ke rumah, rupanya ketika panen sedang berlangsung pun petani pemilik lahan juga menginzinkan siapapun untuk ngasak ${ }^{1}$. Selama ngasak, pemilik lahan menyadari bahwa sebenarnya segala bentuk sisa hasil panen masih bisa dikumpulkan dan diolah sebagai hasil panen yang layak. Namun sebagai bentuk kepedulian sosial, mereka tidak menyisir hasil-hasil panen yang tercecer agar mereka yang ngasak mendapat hasil yang lebih banyak. Sebab pemilik lahan menyadari betul bahwa mereka yang ngasak adalah mereka yang sangat berkekurangan secara finansial. Atas dasar alasan itu, kerap kali pemilik lahan memberikan hasil panen secara sukarela kepada

\footnotetext{
${ }^{1}$ Ngasak adalah aktivitas mengais dan/atau mengumpulkan sisa-sisa hasil panen yang masih tercecer dan tidak terpungut selama panen. Ngasak biasa dilakukan di sawah yang sedang atau sudah dipanen.
} 
mereka yang sedang ngasak. Jika yang dipanen adalah gabah, ukuran pemberian biasanya sebanyak satu mangkuk gabah.

Namun demikian, pengumpulan dan analisis data juga mengungkapkan bahwa bentuk filantropis bukan hanya bersifat pemberian. Dalam beberapa kasus, filantropi petani juga diwujudkan dalam bentuk pemberdayaan. Dalam pengalaman pada momentum penanaman padi, misalnya, masyarakat buruh tani diberdayakan untuk bekerja ndaut $^{2}$ dan tandur3. Mereka yang berkekurangan secara finansial selalu mendapatkan prioritas pertama untuk melaksanakan pekerjaan itu. Meski imbalannya adalah uang sekitar 60-75 ribu per hari, pemilik lahan juga biasa membawakan nasi dan lauk untuk dimakan bersama di tengah hari (jam istirahat) di sawah.

\subsection{Filantropi penambang gamping}

Hampir sama dengan pola filantropis masyarakat golongan petani, masyarakat golongan penambang gamping juga mewujudkan amalnya dengan pemberian dan pemberdayaan. Pemberiannya pun seputar pada hasil usahanya, yaitu gamping. Bedanya adalah pemberian yang diberikan bukan hasil usaha yang pokok, melainkan sisa-sisa pengolahan gamping berupa serbuk halus, yang masih bisa dimanfaatkan sebagai campuran semen untuk membangun rumah. Masyarakat Grenden biasa menyebut serbuk itu sebagai kapur.

Cara pemberian kapur bukan melalui pemberian dari rumah ke rumah sebagaimana dilakukan golongan petani dalam memberikan hasil panen, melainkan dengan mengizinkan siapapun yang hendak mengambil kapur ke tumang4. Umumnya, mereka yang meminta kapur hanya mereka yang sedang membangun rumah. Oleh sebab itu penerima pemberian sama sekali tidak mempunyai kriteria ekonomi yang khusus seperti halnya kriteria yang ditetapkan oleh golongan petani. Sudah menjadi tradisi sejak lama, siapapun warga masyarakat yang membutuhkan kapur untuk keperluan pembangunan rumah selalu diizinkan untuk mengambilnya di tumang terlepas dari apapun status ekonominya.

Namun demikian, biasanya mereka tetap meminta izin terlebih dahulu kepada pemilik tumang. Ini merupakan unggah-ungguh masyarakat Jawa di Grenden untuk tetap mengedepankan etika meski telah dipersilakan ataupun telah menjadi tradisi. Selain itu, jika kapur di tumang tidak diambil oleh warga sekitar, biasanya pemilik tumang atau penambang akan menjualnya ke toko bangunan meski dengan harga yang sangat murah.

Sedangkan tipe filantropi dalam bentuk pemberdayaan memunyai pola yang sama dengan golongan petani, yaitu memberikan pekerjaan kepada laki-laki dari keluarga pra sejahtera untuk ngantek ${ }^{5}$ di tumang milik penambang. Pada beberapa kesempatan, mereka yang ngantek juga sekaligus menjadi sopir untuk mengantarkan gamping kepada pemesan atau pabrik semen. Dalam hal ini, penambang memiliki alasan yang tersendiri tentang pemberian pekerjaan kepada mereka. Pada suatu wawancara tentang alasan pemberian pekerjaan, salah satu penambang gamping berinisial LP menjawab: "kan memang saya butuh karyawan pak. Terus menjadi juragan gamping itu di sini pasti kaya-kaya. Jadi ya supaya tidak ada pengangguran dan tidak ada pencurian, kriminal kepada pengusaha gamping. Ya ngasih pekerjaan lah intinya biar tidak ada yang nekat". Berdasarkan kutipan wawancara di atas, jelas setidaknya dapat disimpulkan bahwa penambang gamping cenderung mempunyai status ekonomi yang lebih tinggi daripada golongan lain. Namun kutipan itu juga sekaligus menandakan adanya situasi dilematis pada konteks-konteks tertentu.

\footnotetext{
${ }^{2}$ Ndaut adalah memisahkan bibit padi dari persemaiannya

${ }^{3}$ Tandur adalah menanam padi sesuai dengan formasi yang sudah ditentukan

${ }^{4}$ Tumang merupakan tempat pembakaran atau pengolahan batu gamping dari tambang sahingga menjadi batu gamping yang bisa digunakan sebagai material bangunan.

5 Ngantek adalah aktivitas menjadi kuli (biasa disebut nguli). Hanya saja, istilah ngantek lazim digunakan untuk menyebut kuli di pembakaran atau pengolahan gamping.
} 


\subsection{Filantropi nelayan}

Berbeda dengan filantropis masyarakat golongan petani dan penambang gamping, masyarakat golongan nelayan tidak menyediakan skema pemberian secara cuma-cuma. Dalam masyarakat golongan nelayan, suatu aktivitas yang menggambarkan filantropi adalah ngorjuk. Ngorjuk merupakan aktivitas membantu nelayan atau pemiliki sampan untuk menepikan sampan dari laut ke pantai atau pesisir. Dalam ngorjuk, bantuan yang diberikan kepada nelayan bukan hanya menepikan kapal, melainkan juga menurunkan semua brang yang dibawa dari laut, termasuk sisa perbekalan dan ikan hasil tangkapan. Nah, ikan hasil tangkapan inilah yang diberikan kepada orang-orang yang ngorjuk sebagai imbalan atas bantuan yang diberikan.

Namun begitu, tidak semua masyarakat Grenden melakukan ngorjuk. Selain karena lokasi desa Grenden agak jauh dari laut (sekitar $10 \mathrm{~km}$ ), pemilik sampan hanya mengizinkan kerabatnya saja. Secara etis, ini merupakan ungkapan rasa terima kasih dari pemilik sampan, karena kerabat-kerabat itulah yang menjaga kelurga dan rumah selama ia melaut beberapa hari. Kajian lebih lanjut justru menampakkan bahwa kerabat inilah yang kemudian memberikan sejumlah kecil hasil tangkapan laut kepada individu-individu tertentu di desa Grenden. Praktis, ada dua corak filantropi yang bisa ditegaskan dalam penjabaran ini. Pertama filantropi masyarakat golongan nelayan memberikan amal dalam bentuk pemberdayaan, dan kedua penerima manfaat atas amal yang diberikan nelayan kembali membagikan pemberian nelayan kepada orang lain yang dianggap termasuk keluarga pra sejahtera.

\subsection{Nilai pendidikan profetik}

Sebuah riset historis oleh Jusuf (2007) telah secara gamblang menyimpulkan bahwa filantropi bersumber dari agama, terutama agama-agama samawi. Apabila ditelusuri lebih lanjut, tren ini disebabkan adanya anjuran keagamaan dan/atau kenabian untuk tidak hanya melaksanakan ibadah yang sifatnya ritual, melainkan juga ibadah yang sifatnya sosial. Pedoman inilah yang kemudian banyak dianut oleh masyarakat Grenden sehingga tercipta iklim filantropi tradisional yang awet, rutin, dan secara sosiologis disebut sebagai kegiatan berbasis paguyuban. Besaran pemberian dalam filantropi sering kali tidak diketahui, karena aktivitas filantropi masih bersifat interpersonal. Ia merupakan hidden action (tidak dilakukan di depan umum) dan tidak terkoordinasi secara institusional.

Dalam kaitannya dengan pendidikan karakter, filantropi di atas mewakili karakter religius dan karakter sadar akan hak dan kewajiban diri dan orang lain. Asumsi ini diperkuat selain oleh pemahaman agama masyarakat Grenden yang memerintahkan individu untuk berbuat kebaikan secara ikhas, tetapi juga oleh pemahaman kejawaan yang menghimbau masyarakat untuk membantu orang lain terlepas dari apapun statusnya dan bagaiamanapun kondisinya.

Menurut pemahaman kejawaan yang dianut masyarakat Grenden, suatu saat nanti akan tiba kondisi dimana individu tidak bisa melakukan suatu hal tanpa bantuan orang lain. Salah satu contohnya ialah momentum kematian, yang membutuhkan partisipasi keluarga dan tetangga untuk melakukan serangkaian prosesi persiapan pemakaman, pemakaman, dan pasca pemakaman. Serangkaian prosesi itu semisal gelaran slametan, doa bersama (tahlilan), haul, dan lain-lain (Nasir, 2019). Filantropi yang dilakukan selama ini juga dimaksudkan untuk mengantisipasi moment-moment darurat dan mendesak seperti itu. Terlebih lagi orang-orang Grenden merupakan masyarakat Jawa yang menghayati konsep Sangkan Paraning Dumadi, yang berarti kembali kepada sumber atau kembali kepada yang menciptakan (Waston, 2018). Jika tiba saatnya masyarakat kembali kepada Tuhan, maka mereka harus dalam kondisi bersih dan telah memberikan manfaat kepada sesama manusia. Pada taraf ini, tampaklah adanya nilai karakter dalam hubungannya dengan Tuhan, diri sendiri, dan sesama manusia.

Sebagaimana masyarakat tradisional yang beragama (Saidi, 2006), masyarakat Grenden mempunyai interpretasi yang tidak beragam atas makna pemberian. Bagi 
masyarakat Grenden, semua bentuk filantropi tidak dikelompokkan ke dalam zakat, infaq, sadaqah, maupun waqaf. Ini sangat berbeda dengan masyarakat Jember di Desa Sukoreno, Kec. Umbulsari. Di sana, menurut penelitian Tamin (2011), masayarakat petani jeruk berfilantropi melalui sejumlah skema pemberian di atas. Pada skema zakat, misalnya, petani hanya akan mengeluarkan zakat maal manakala hasil panen telah memenuhi syarat minimal untuk berzakat. Target penerimaan zakat dibedakan secara dikotomis menjadi masyarakat miskin dan lembagas masjid. Khusus kategori masyarakat miskin, cakupannya sangat khusus dan terbatas, yaitu memiliki kriteria berupa: (1) tidak mempunyai lahan pertanian, baik lahan sewa maupun lahan garapan, (2) bentuk rumah sangat sederhana atau belum banyak bagian yang dibangun menggunakan semen, dan (3) merupakan usia lanjut baik duda maupun janda.

Hal yang sama juga berlaku dalam skema infaq, sadaqah, dan waqaf yang tidak memperhatikan aspek yuridis religius. Bagi masyarakat Grenden, tidak penting apakah pemberian itu termasuk ke dalam zakat, infaq, sadaqah, ataupun waqaf. Sejauh pemberian itu bisa meringankan perekonomian orang lain, maka pemberian itu sudah dianggap sebagai representasi dari nilai budaya Jawa dan nilai keislaman yang selama ini dianut.

Penyelidikan secara lebih intensif dalam penelitian ini juga mengungkap fakta lain, bahwa rupanya filantropi sebagai tradisi budaya dan agama diwariskan secara kebudayaan. Ini mengindikasikan pendidikan non formal telah terlaksana dengan baik pada kalangan masyarakat Grenden. Pendidikan non formal ini merupakan solusi atas masalah pendidikan karakter dalam bidang studi PAI di lembaga formal. Sejauh ini, pendidikan karakter melalui PAI cenderung berada pada posisi problematik antara determinisme historis dan realisme praktis (Arif, 2008). Pendidikan non formal dalam masyarakat Grenden kemudian menjadi solusi karena mempromosikan pendidikan profetik yang diselenggarakan secara kebudayaan.

Dikatakan demikian karena filantropi tradisional yang dipraktikkan masyarakat Grenden berlandaskan kepada nilai-nilai kemanusiaan (humanisme), sehingga orientasinya tidak terfokus pada urusan surga-neraka ataupun pahala-dosa. Orientasi nilai pendidikan profetik masyarakat Grenden mengacu kepada pemenuhan hasrat untuk membentuk masyarkat yang beradab tanpa memaksakan kehendak secara kaku. Dengan demikian, masyarakat bisa merasakan suasana iklim sosial yang inklusif bagi semua tipe individu, termasuk individu difabel, ODGJ, maupun individu dengan karakteristik khas lainnya (Miftakhuddin, 2018). Ini persis dengan temuan Solikhin (2020) yang mengungkapkan bahwa salah satu visi pendidikan profetik adalah melaksanakan kewajiban peribadatan ritual dan sosial secara seimbang.

\subsection{Otokritik motivasi filantropi}

Secara historis, karakter sebagain kecil masyarakat Pulau Jawa yang jauh dari nilai profetik memang sulit untuk dibenahi, karena di masa lampau perilaku semacam korupsi dan menimbun harta pernah mempunyai legalitas yang sah sebagai register kebudayaan dan praktik sosial (Miftakhuddin, 2019a). Situasi yang agak dilematis juga ditemukan dalam penelitian ini.

Terlepas dari sekian banyak nilai pendidikan karakter dalam praktik filantropi masyarakat Grenden, ada problem mendasar yang berkaitan dengan tahap-tahap perkembangan moral sebagaimana dirumuskan oleh Kohlberg (1995). Problem ini ialah perilaku filantropi yang dilakukan atas dasar rasa kewajiban beragama. Seperti pernah disinggung di bagian Pendahuluan, salah satu alasan perilaku filantropi ialah kewajiban untuk menjalankan perintah agama. Artinya, suatu kegiatan filantropi belum tentu dilakukan atas dasar rasa kemanusiaan, melainkan oleh keinginan untuk memperoleh pahala, rasa aman atas masa mendatang, sekadar menggugurkan kewajiban beragama, dan berharap memperoleh bantuan yang setimpal andaikata ia mengalami kesusahan. Namun begitu, perlu dipertegas dalam bagian ini bahwa pemahaman yang demikian tidak 
dominan, bahkan cenderung sangat minim. Ini tergambar dalam salah satu kutipan wawancara kepada informan SP berikut, yang ketika ditanya mengapa ia memberikan sebagian hasil panen menjawab: "sebagai muslim memang wajib memberikan bantuan kepada mereka yang butuh. Sudah diwajibkan, ya harus dilakukan. Biar dapat ganjaran. Biar nanti gantian ditolong kalau butuh pertolongan".

Menurut teori perkembangan moral, alasan berperilaku baik yang didasarkan atas motivasi keuntungan pribadi menunjukkan bahwa perkembangan moral seseorang masih di tahap awal. Individu yang telah mencapai level perkembangan moral lebih tinggi biasanya melakukan perilaku baik atas dasar motivasi menjaga kestabilan sosial, kemanusiaan, dan rasa empati-simpati (Crain, 2014). Berdasarkan penelitian ini, level perkembangan moral yang demikian telah dicapai oleh golongan masyarakat yang tidak dominan (minoritas), yaitu golongan pegawai negeri, tenaga kesehatan, dan ulama lokal. Meski demikian, filantropis masyarakat Grenden perlu diapresiasi sebagai suatu solusi atas masalah pendidikan karakter yang selama ini diterapkan dalam institusi pendididkan formal. Masyarakat sebagai penyelenggara pendidian non formal dalam hal ini mampu melaksanakan peran-peran etis untuk mewariskan nilai edukasi secara kebudayaan.

Pada masyarakat golongan pegawai negeri, filatropi biasanya didasarkan atas rasa saling terikat sebagai satu kesatuan masyarakat. Bagi mereka, sistem kemasyarakatan seharusnya diatur oleh ikatan sosial bercorak primordialisme. Oleh sebab itu segala bentuk filantropi biasa diberikan oleh golongan pegawai negeri tanpa memandang status ekonomi maupun status kekerabatan. Pada tenaga kesehataan, filantropi biasanya dilakukan atas dasar nilai kemanusiaan. Oleh sebab itu tenaga kesehatan akan tetap memberikan layanan kesehatan, edukasi, dan promosi perilaku hidup sehat walaupun beberapa warga masyarakat melakukan penolakan. Salah satu contoh yang sangat jelas ialah edukasi perilaku hidup sehat yang baru-baru ini dipromosikan selama pandemi covid-19. Adapun ulama lokal biasa menampakkan praktik filantropi berbasis religi. Bentuknya ialah pemberian karitas yang ditepatkan pada momen-momen tertentu (misal: peringatan hari besar islam seperti maulid nabi, tahun baru islam, isra' mi'raj, dan lain sebagainya).

Berdasarkan penelitian ini, filantropi yang ditampakkan oleh ulama lokal mempunyai pengaruh yang sangat besar dalam membentuk register kebudayaan, keagamaan, dan tradisi masyarakat Grenden. Penelitian ini pada akhirnya mengkonfirmasi temuan Horikoshi (1987) bahwa kyai tradisional pada akhirnya memperoleh otoritas dan kedudukan yang kudus di mata masyarakat. Atas dasar privilege ini, ulama lokal pada gilirannya turut menentukan arah pendidikan non formal di masyarakat menjadi bermuatan nilai pendidikan profetik, yaitu pendidikan yang berdasarkan nilai-nilai kebaikan yang mencerminkan sifat-sifat baik atau karakter unggul dari Muhammad (Roqib, 2013). Karena diselenggarakan secara kebudayaan dan tradisional, model pengajaran dan pendidikan non formal oleh masyarakat Grenden tidak mempunyai struktur kurikulum yang spesifik dan fase-fase pembelajarannya pun tidak baku seperti halnya pendidikan agama di pesantren. Sebagai pendidikan profetik, sebagaimana disebutkan Masrifatin (2020), dasar-dasar edukasi yang dijadikan pijakan selalu terinspirasi dari perilaku kenabian dari Muhammad. Pola yang demikian sangat cocok untuk mendidik individu-individu yang perkembangan kognitifnya sudah di fase operasional formal (usia remaja awal sampai dewasa atau usia SMP ke atas). Sebab, perilaku filantoropis dan praktik-praktis sosial kebudayaan lainnya membutuhkan kemampuan menalar dan menginterpretasikan konsep-konsep abstrak melalui material pengajaran yang faktual, aktual, dan kontekstual (Khoiron et al., 2020).

\section{Kesimpulan}

Sebelum menengenal adanya berbagai bentuk bantuan dari pemerintah, masyarakat Grenden sudah sejak lama menjalankan tradisi untuk merespon isu kemiskinan melalui sejumlah bentuk pemberian. Term "pemberian" yang dipahami masyarakat Grenden tidak 
terbatas dalam bentuk uang atau barang, melainkan juga bisa pekerjaan atau berbagai upaya lain untuk meringankan beban individu miskin serta membantu meningkatkan kesejahteraannya. Serangkaian praktik filantropi itu didasari atas nilai budaya Jawa dan nilai keagaman islam.

Sebagai konsekuensi atas landasan filosofis itu, aktivitas filantropis menjadi bermuatan pendidikan profetik. Nilai pendidikan ini secara kebudayaan diwariskan kepada generasi muda, sehingga ditinjau dari perspektif ilmu pendidikan, nilai pendidikan profetik yang dipromosikan masyarakat tetap lestari melalui pendidikan non formal yang bercorak humanistik. Implikasi penelitian ini, oleh karenanya, adalah koreksi terhadap dasar-dasar pendidikan karakter selama ini yang porsinya terlalu banyak mengadopsi pedoman dari Barat. Hasil penelitian ini menunjukkan bahwa kearifan lokal dalam masyarakat adalah sumber yang ideal untuk menyelenggarakan pendidikan karakter. Dikatakan ideal karena kearifan lokal mempunyai kedekatan emosional, kultural, dan intelektual dengan anak didik di sekolah-sekolah Indonesia.

Temuan penelitian ini berkontribusi kepada pengembangan ilmu pendidikan, terutama pendidikan karakter. Penelitian ini menawarkan solusi atas masalah pendidikan karakter yang selama ini harus diselenggarakan dengan menunjukkan role model terlebih dahulu. Penelitian ini memandang bahwa tidak semua manusia bisa berperilaku baik dengan sempurna. Oleh sebab itu penelitian ini tidak mengandalkan role model untuk dijadikan pedoman untuk membentuk karakter. Menurut temuan dalam penelitian ini, karakter bisa dibentuk tanpa berpedoman kepada role model manusia, melainkan berpedoman kepada karakter unggul yang dicitrakan oleh Muhammad. Citra ini bisa diinternalisasi melaui kegiatan-kegiatan filantropis masyarakat tradisional yang masih mengantu kebudayaan dan agama secara taat. Demikianlah bisa diperoleh pendidikan profetik yang mampu membentuk karakter siswa tanpa melalui role model secara langsung.

\section{References}

[1] Arif, M. (2008). Pendidikan islam transformatif. LKiS.

[2] Bandura, A. (1977). Social learning theory. Prentice-Hall.

[3] Berg, B. L. (2004). Qualitative research methods for the social sciences (5th ed.). Pearson Education.

[4] Crain, W. (2014). Theories of development: Concepts and applications (6th ed.). Pearson Education.

[5] Dyer, J. H., Gregersen, H. B., \& Christensen, C. M. (2011). The innovator's DNA: Mastering the five skills of disruptive innovators. Harvard Business School.

[6] Gufron, A., Budiningsih, C. A., \& Hidayati. (2017). Pengembangan pembelajaran berbasis nilai-nilai budaya Yogyakarta di Sekolah Dasar. Cakrawala Pendidikan, 37(2), 309-319.

[7] Hidayat, F. (2018). Viral guru dibully murid, sekolah akan perkuat pendidikan karakter. Detik.com. https://news.detik.com/berita/d-4299012/viral-guru-di-bully-murid-sekolah-akan-perkuat-pendidikan-karakter

[8] Horikoshi, H. (1987). Kyai dan perubahan sosial. P3M

[9] Judiani, S. (2010). Implementasi pendidikan karakter di sekolah dasar melalui penguatan pelaksanaan kurikulum. Jurnal Pendidikan Dan Kebudayaan, 16(3), 280-288

[10] Jusuf, C. (2007). Filantropi modern untuk pembangunan sosial. Jurnal Penelitian Dan Pengembangan Kesejahteraan Sosial, 12(1), 74-84. https://doi.org/10.33007/ska.v12i1.621

[11] Kemendiknas. (2011). Pendidikan karakter di sekolah menengah pertama. Kemdiknas.

[12] Khoiron, M., \& Wahyuningtyas, N. (2020, February). Revitalization of Social Studies Education: A Developmental Study Based on Dick and Carey Instructional Design. In International Conference on Social Studies and Environmental Issues (ICOSSEI 2019) (pp. 37-42). Atlantis Press. https://doi.org/https://dx.doi.org/10.2991/assehr.k.200214.007 
[13] Kohlberg, L. (1995). Tahap-tahap perkembangan moral (Terj. John de Santos dan Agus Cremes). Kanisius.

[14] Latifah, N. (2021). Cegah dan tuntaskan kenakalan remaja dengan pendidikan karakter. Jawapos.com. https://radarsemarang.jawapos.com/rubrik/untukmu-guruku/2021/03/31/cegah-dan-tuntaskan-kenakalan-remajadengan-pendidikan-karakter/

[15] Lubis, R. R. (2019). Historisitas dan dinamika pendidikan karakter di Indonesia. An-Nahdhah, 1(2), 70-82.

[16] Masrifatin, Y. (2020). Konsep pendidikan profetik sebagai pilar humanisasi. Lentera: Kajian Keagamaan, Keilmuan, Dan Teknologi, 1(1), 274-282.

[17] Miftakhuddin, M. (2018). Kecenderungan Putus Sekolah Difabel Usia Pendidikan Dasar di Jember. INKLUSI Journal of Disability Studies, 5(1), 95-114. https://doi.org/10.14421/ijds.050105

[18] Miftakhuddin, M. (2020). Historiografi Korupsi di Indonesia: Resensi Buku Korupsi dalam Silang Sejarah Indonesia. Rihlah: Jurnal Sejarah dan Kebudayaan, 7(2), 168-172. https://doi.org/10.24252/rihlah.v7i2.11772

[19] Miftakhuddin, M. (2019). Dedication of Unej Mengajar to Improve the Human Resources' Quality in the Retarded Areas of Jember through a Participatory Approach. Proceeding of Community Development, 2, 454-466. https://doi.org/10.30874/comdev.2018.463

[20] Miftakhuddin, A. M., \& Zulfiati, H. M. (2019). Misconceptions between Social Studies and Social Sciences among Pre-Service Elementary Teachers. International Journal of Education, 12(1), 16-25. https://doi.org/10.17509/ije.v12i1.17514

[21] Miles, M. B., Huberman, A. M., \& Saldana, J. (2014). Qualitative data analysis: A methods sourcebook (3rd ed.). Sage Publication. https://doi.org/10.1080/0140528790010406

[22] Nasir, M. A. (2019). Revisiting the Javanese Muslim Slametan: Islam, local tradition, honor and symbolic communication. Al-Jami'ah, 57(2), 329-358. https://doi.org/10.14421/ajis.2019.572.329-358

[23] Noormawanti, N. (2017). Pendidikan karakter di Indonesia dalam tinjauan psikologis. At-Tajdid: Jurnal Pendidikan Dan Pemikiran Islam, 1(01), 124-136. https://doi.org/10.24127/att.v1i01.339

[24] Rahardjo. (2017). Pengantar sosiologi pedesaan dan pertanian. UGM Press.

[25] Rogib, M. (2013). Pendidikan karakter dalam perspektif profetik. Jurnal Pendidikan Karakter, 3(3), 240-249.

[26] Saidi, Z. (2006). Kedermawanan untuk keadilan sosial. Piramedia.

[27] Salirawati, D. (2021). Identifiksi problematika evaluasi pendidikan karakter di sekolah. Jurnal Sains Dan Edukasi Sains, 4(1), 17-27. https://doi.org/10.24246/juses.v4i1p17-27

[28] Sanjaya, R. (2021). Pentingnya pendidikan karakter zaman digital. Kompas.com. https://www.kompas.id/baca/opini/2021/03/08/pentingnya-pendidikan-karakter-zaman-digital/

[29] Schreiber, J., \& Asner-Self, K. (2011). Educational Research. John Wiley \& Sons.

[30] Solikhin, M. (2020). De-Radicalization through prophetic education in high school. Nadwa: Jurnal Pendidikan Islam, 14(1), 155-174. https://doi.org/10.21580/nw.2020.14.1.5707

[31] Spradley, J. P., \& McCurdy, D. W. (2012). Conformity and Conflict: Readings in Cultural Anthropology. Pearson Education.

[32] Tamin, I. H. (2011). Peran filantropi dalam pengentasan kemiskinan di dalam komunitas lokal. Jurnal Sosiologi Islam, 1(1), 35-58.

[33] Waston. (2018). Building peace through mystic philosophy: Study on the role of Sunan Kalijaga in Java. Indonesian Journal of Islam and Muslim Societies, 8(2), 281-308. https://doi.org/10.18326/ijims.v8i2.281-308 